\title{
Tax Awareness, Taxpayers' Perceptions and Attitudes and Tax Evasion in Informal Sector of Ekiti State, Nigeria
}

\author{
Oluyinka Isaiah Ogungbade ${ }^{1}$, Adekunle Enitan ${ }^{1} \&$ Adeleke Clement Adekoya ${ }^{1}$ \\ ${ }^{1}$ Department of Accounting, Afe Babalola University, Ado-Ekiti, Nigeria \\ Correspondence: Oluyinka Isaiah Ogungbade, Department of Accounting, Afe Babalola University, Ado-Ekiti, \\ Nigeria.
}

Received: August 5, 2020

Accepted: November 9, 2020

Online Published: June 22, 2021

doi:10.5430/ijfr.v12n5p24

URL: https://doi.org/10.5430/ijfr.v12n5p24

\begin{abstract}
Nigeria has been desperately seeking tax revenues since 2016 due to a persistent fall in oil price and production. However, many Nigerians are not tax compliant since there was little or no emphasis on tax revenue, particularly in the informal sector during the oil boom. This paper examined the effect of Tax awareness and Taxpayers' perception of government spending on Tax evasion in the informal sector of Ekiti state. Also, the moderating effect of Taxpayers' attitude was examined. A structured questionnaire was used to collect data from 150 respondents, but only 108 returned the completed questionnaire, and only 100 respondents' data were useful. The findings show that Taxpayers' awareness considerably reduced tax evasion, but the effect of Taxpayers' perception lacks analytical support. The findings also reveal that taxpayers' attitude has a significant moderating effect on the relationship between taxpayers' awareness and tax evasion. However, the moderating effect of Taxpayers' attitude on the relationship between Taxpayers' perception about government spending and Tax evasion was not statistically significant.
\end{abstract}

Keywords: tax awareness, taxpayers' perceptions, taxpayers' attitudes, tax evasion, informal sector

\section{Introduction}

Nigeria is the largest economy in Sub-Saharan Africa, and it relies heavily on oil revenue. The heavy reliance on oil revenue has contributed to high tax evasion in the country. However, the oil-rich Nigeria is characterised by the inadequate power supply, dilapidated infrastructures, unemployment and abject poverty. Nigeria entered recession in 2016 due to persistent fall in oil prices, and production, which was aggravated by militant attacks on oil and gas infrastructure and detrimental economic policies. The poor state of the nation's economy opened the eyes of the government to tax revenue which was not given adequate attention during the era of the oil boom.

The economic development of any nation is contingent on the revenue's generation and its availability for both capital and recurrent expenditure (Assfaw \& Sebhat, 2019). In Nigeria, tax revenues mainly come from the formal sector (companies, organisations and salaries earners) while the informal sector has been widely neglected. Tax revenues have been very difficult to maximise due to various forms of tax evasion; thus, tax evasion is a major societal problem that is hindering development in Nigeria (Mansor \& Gurama, 2016).

It has been made known that people do not like to pay taxes. Because of this fundamental reason, it is hard for tax administrators to levy and collect taxes efficiently most notably from the informal sector thus making the taxing of the informal sector a significant challenge for tax administrators in both developed and developing countries.

According to Mansor and Gurama (2016), tax evasion is one of the major social problems inhibiting development in developing countries and eroding the existing welfare state in developed economies. Tax evasion is a form of tax fraud which could be due to non-payment or underpayment of tax liabilities, failure to file tax returns, filing of incomplete or inaccurate returns and failure to register for tax purposes(Olaoye \& Ogundipe, 2018).

Taxation plays a crucial role in national budget preparation and implementation. It is one of the principal sources of government revenue. When citizens do not pay taxes, it affects budget planning, budget preparation and government spending. That is why evasion of tax is linked directly to the budget deficit and hence the lower revenue collection as well as investments in public goods. Tax evasion can be said to be inimical to a country's growth (Assfaw \& Sebhat, 2019; Mansor \& Gurama, 2016). 
Currently, in Nigeria, there is dwindling oil revenue which has resulted in a shift from crude oil-driven economy to tax-driven economy. Government effort is now geared towards improved and effective tax system. Tax policies are being reviewed to ensure seamless tax administration. State governments have had to embrace taxonomy as a means of augmenting shortfall in their monthly federal allocation. It has become apparent that tax revenue is a principal means for the government to perform its role of providing social goods effectively.

Despite the ongoing tax drive, various tax campaigns and tax initiatives by the government, the informal sector is still yet to be brought fully into the tax net. The informal sector of an economy is a significant challenge in tax administration about collection or payment of tax, especially in developing countries hence the 'hard to tax' sector. The informal sector is difficult to tax because of the administrative challenges, which include their vast number and variability and mobility in their operations (Dube \& Casale, 2016). Informal sector economy and tax evasion have become an integral part of Nigeria's economy with a considerable positive and negative effect. Tax revenues from the informal sector will have a considerable positive effect on the Nigerian economy, while tax evasion has a robust negative effect on the economy (Omodero, 2019). Also, existing literature suggests that the government should formulate policies to ensure voluntary tax compliance and bring legitimate informal sector enterprises to tax net (Omodero, 2019).

They further noted that the "fiscal gap" that arises from the failure to tax this sector could be quite large. There is, therefore, need to examine the taxpayers' perception and attitude in the informal sector with regards to tax evasion. The perception and attitudes of individual taxpayers especially those in the hard to tax sector that encourages them to evade taxes or not to comply with tax payment particularly in Ado-Ekiti metropolis are not known and its effect on tax evasion. Therefore, the need to examine the perception and attitudes of these taxpayers becomes crucial. Even though research works have been carried out on tax evasion and also the taxation of the informal sector, few studies have been carried out on the influence taxpayers' perceptions, and attitudes have on taxpayers that makes them evade tax in developing countries like Nigeria especially in Ado-Ekiti, hence, this study. Moreover, none of the previous studies examined the moderating effect of taxpayers ' attitude on the relationship between the taxpayers 'awareness of tax responsibility, their perceptions about tax and tax evasion. The remainder of this paper is organized as follows: Section 2 comprises literature review, section 3 discusses methodology, section 4 comprises the results and discussion and section 5 comprises conclusion and recommendation.

\section{Literature Review}

This chapter comprises conceptual clarifications, theoretical reviews, empirical review and the methodology employed for achieving the objectives of the study.

\subsection{Conceptual Clarifications and Empirical Review}

This chapter also discusses the various concepts relating to the study for a more in-depth understanding of the variables used in the study.

\subsubsection{Taxpayers 'Awareness and Tax Evasion}

Tax evasion can also be described as illegal means of avoiding paying taxes which usually involves misrepresentation of income to the revenue board either in the form of underreporting income or inflating deductions (Alqtish, Alqirem, \& Kasem, 2018).

Awareness is the consciousness of the human element in the understanding of reality and how to react or respond to reality. Thus, tax awareness is the consciousness of taxpayers of their civic responsibilities to pay Tax (Hartikayanti \& Siregar, 2019). Taxpayers' awareness refers to consciousness, alertness and knowledge of the taxpayers of their civic responsibility to pay tax. Since Nigeria has concentrated on oil revenue for a long time and paid little or no attention to tax revenue, it is not unexpected that the supposed taxpayers have never been alerted to pay tax. The extent to which the taxpayers are informed about tax is very fundamental for every successful tax system.

The analysis of primary data collected from 150 respondents in India via a five-point Likert Scale structured questionnaire shows that tax awareness reduces tax evasion. The 85 responses from the 150 respondents were analysed via z-test, and the results show that taxpayers in India evade tax due to bad governance and high level of tax -illiteracy (Lodha, Sheikh, \& Soral, 2017).

In Ethiopia, the empirical finding reveals that Tax Knowledge and tax awareness of taxpayers, taxpayers' Attitude and taxpayers' perceptions of government spending have a positive effect on tax compliance. It implies that the more awareness and knowledge of tax that the taxpayers have, the more positive attitude they have, and the more positive perception of government spending of taxpayers' money they have, the less they evade tax. (Assfaw \& Sebhat, 
2019).The data were collected from randomly selected 311 respondents via a structured questionnaire and analysed with the aid of logistic regression.

In the same vein, a study from Jordan which collected data from (492) taxpayers and (471) employees of income and sales tax department as respondents for the research questionnaire, posits that both contextual tax awareness and ethical tax awareness have a positive effect on tax evasion among the two categories of respondents(Zhang, Abukhadijeh, \& Qasem, 2016). Similarly, the analysis of the data collected from purposively selected 100 respondents at the primary tax office in Kalimantan, Indonesia reveals that tax knowledge, tax morale, tax system, tax fairness and tax compliance cost considerably influence tax compliance. The higher the knowledge of taxpayers of the tax, the less the possibility of evading tax. (Rantelangi \& Majid, 2018)

Similarly, the analysis of the data collected from purposively selected 100 respondents at the primary tax office in Kalimantan, Indonesia reveals that tax knowledge, tax morale, tax system, tax fairness and tax compliance cost considerably influence tax compliance. The higher the knowledge of taxpayers of the tax, the less the possibility of evading tax. (Rantelangi \& Majid, 2018) In like manner, existing literature suggests that tax knowledge is the most crucial tax system characteristic that affects taxpayers' attitude of whether to evade tax or not (Pui, Moorthy, \& Choo, 2017).

In contrast, in another study carried out in Ethiopia, which also used primary data collected from 332 respondents, and logistic regression, Tilahun (2018) found out that tax awareness has a negative but insignificant effect on tax compliance. Similarly, the existing literature shows that the higher the awareness level of taxation by the taxpayer, the higher the degree of tax evasion because the educated and knowledgeable taxpayers understand the opportunities for tax evasion than less educated or less knowledgeable taxpayers (Beesoon, Hemavadi, \& Jugurnath, 2016; Chuenjit, 2014; Ndekwa, 2014; Saad, 2014). The existing literature has produced the confounding results on the effect of tax awareness on tax evasion. The studies were also carried out an informal sector of the economy; however, this study examined the effect of tax awareness on tax evasion in the informal sector. Therefore, the study tested the following hypothesis:

$\mathrm{H}_{0}$ 1: Tax awareness does not have a significant effect on tax evasion among the informal enterprises in Ekiti state.

\subsubsection{Taxpayers Perception About Tax and Tax Evasion}

Perceptions of taxpayers play a crucial role for taxpayers to correctly fulfil their tax obligations(Mitu, 2018). The taxpayers' perception that tax authorities are sincere with the purpose of tax collection, and the individual morality or right attitude foster voluntary tax compliance among SMEs in Greece (Kaplanoglou, Rapanos, \& Daskalakis, 2016). Likewise, in Malaysia, a study which used convenient sampling technique to select 419 respondents and employed regression analysis revealed that taxpayers perceptions about government spending are one of the significant factors that determine tax evasion(Sritharan \& Salawati, 2019). The study established that taxpayers perception about government spending significantly increased tax compliance. Similarly, findings from Italy reveals that taxpayers perceptions about government spending determine tax compliance as there were tax evasions in the area where there were complaints about public goods while citizens were eager to pay tax in the area where there were not enough public goods and the citizens believed their tax payments would enhance the delivery of public goods to their community (Elena, Alberto, \& Giuseppe, n.d.).

In contrast, assessment of taxpayers attributes on tax compliance using 5pont Likert scale and ordinary least square linear regression reveals that taxpayers' perception of government spending does not significantly influence tax compliance, while taxpayers attitude significantly influence tax compliance (Aronmwan \& Eragbhe, 2015). Likewise, Engida and Baisa (2014) posit that the perception of government spending does not affect tax evasion. Similarly, Razak and Adafula (2013) argue that the level of governmental accountability and transparency does not considerably impact on taxpayers' attitude (Razak \& Adafula, 2013).

\subsubsection{Taxpayers Awareness, Taxpayers Perceptions of Government Spending, Taxpayers Attitude and Tax Evasion}

Taxpayers' attitudes may be described as positive or negative views of tax compliance behaviour. The positive views lead to voluntary compliance, while the negative views lead to tax evasion (Mitu, 2018). Furthermore, the existing literature shows that taxpayers' attitude of tax morality considerably determines taxpayers' perceptions of tax evasion in Malaysia. This study implies that when tax evasion is perceived as immoral or unacceptable, it will discourage taxpayers from evading taxes (Pui et al., 2017).

Taxpayers attitude towards tax evasion has a significant positive effect on tax compliance behaviour (Alabede, Ariffin, \& Idris, 2011). In the same manner, studies from Nigeria show that taxpayers attitude has a significant 
positive effect on compliance. In contrast, taxpayers' perception does not have a statistically significant effect on tax compliance (Aronmwan \& Eragbhe, 2015).

Taxpayers perceptions of benefits derived from tax payment in the form of provision of goods and services were high in Chana. However, the taxpayers' perceptions of tax burden affect their attitude and which eventually determine their tax compliance. The level of governmental accountability and transparency does not considerably impact on taxpayers' Attitude (Razak \& Adafula, 2013).

It was discovered that the reviewed studies did not only produce mixed results, they also focused on the formal sector, and the studies from Nigeria on the subject matter are insufficient. Moreover, the existing studies did not examine the moderating effect of taxpayers' attitude on the relationship between taxpayers' awareness and tax evasion and on the relationship between taxpayers' perceptions about government spending and tax evasion. Therefore, this study shall also contribute to knowledge by statistically providing answers to the effect of Taxpayers awareness, Taxpayers perception of Government spending and Taxpayers' Attitude on tax evasion. Therefore, the study tested the following hypotheses:

$\mathrm{H}_{02:}$ Taxpayers' perception of government spending does not have a significant effect on tax evasion in the informal sector of Ado-Ekiti.

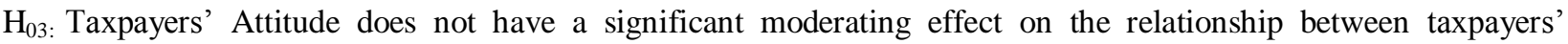
awareness of their civic responsibilities to pay tax and tax evasion among the taxpayers in the informal sector of Ado-Ekiti.

$\mathrm{H}_{04}$ : Taxpayers' Attitude does not have a significant moderating effect on the relationship between taxpayers' perceptions about government spending and tax evasion among the taxpayers in the informal sector of Ado-Ekiti.

\subsubsection{Conceptual Framework}

The conceptual framework model developed below showed the individual and the mutual relationship between the independent variables, moderating and the dependent variables. The taxpayers' awareness and perceptions are the independent variables; the taxpayers' attitude is the moderating variable, while the tax evasion by the informal sector is the dependent variable. The moderator variable is a third variable that affects the strength of the relationship between a dependent and independent variable by causing an amplifying or weakening effect between the main variables.



Figure 1. The conceptual framework

Source: Author, 2020

\section{Methodology}

\subsection{Research Design}

The survey research design was used in this study to obtain facts about the study and to draw a valid general conclusion from the facts discovered. The survey design is used in analytical studies to allow the researcher to gather 
information, summarise, present data and interpret it. Moreover, this is considered appropriate because survey design generally can be used to investigate problems in realistic settings effectively.

\subsection{Population, Sample Size and Sampling Technique}

The population of this research work was unregistered business entities that constitute the informal sector of Ado-Ekiti Metropolis. Informal sector businesses that registered with their association in Ado Ekiti metropolis were about 500. A sample size of 150 unregistered business owners in Ado-Ekiti metropolis which represent $30 \%$ of the population was purposively selected, and the researcher personally administered the questionnaire to them. However, only 108 returned the completed questionnaire, but 8 of them were not filled, which made them not useful for this study. Consequently, the study used the remaining 100 copies of the questionnaire.

\subsection{Data Collection, Description and Operationalisation of Variables}

For this research, a close-ended questionnaire was designed to obtain the necessary and relevant data, this is because, of a large number of respondents. The questionnaire items were based on the Likert five-point rating scale of Strongly Agree (SA), Agree (A), Undecided (U), Disagree (D) and Strongly Disagree (SD). Respondents were requested to respond by putting a tick $(\sqrt{ })$ in the front of the item of their choice. The questionnaire was personally administered to the respondents by the authors.

Taxpayers' attitudes may be described as positive or negative views of tax compliance behaviour. The positive views lead to voluntary compliance, while the negative views lead to tax evasion (Mitu, 2018). Taxpayer attitude to tax evasion is in three dimensions which comprise taxpayers' belief about tax evasion; feeling about tax evasion and behaviour (Alabede et al., 2011). The three dimensions of the taxpayer's attitude towards tax evasion were measured using the instrument developed by (Eriksen \& Fallan, 1996) and used by other authors(Alabede et al., 2011). On a Likert scale 1-5, the responses below three (3) are regarded as negative attitude while responses from above 3 to 5 are regarded as a positive attitude

Similarly, Taxpayers awareness was measured on a five-point Likert scale using five items derived from the instruments of the previous authors (Assfaw \& Sebhat, 2019; Lodha et al., 2017; Zhang et al., 2016). In like manner, Taxpayers perception about government spending and Tax evasion was measured on a five-point Likert scale.

\subsection{Validity and Reliability of Research Instrument}

The validity and reliability of the instrument were determined before administering it to the respondents. First, the questions were framed in such a manner that they were easily understood and accurately conveyed their sense and purpose to the respondents. The content analysis was done by ensuring that the instrument was in line with related literature on tax perception, attitude and tax evasion. The logic and sequence of the research instrument were confirmed by Cronbach's Alpha coefficient, which measures internal consistency. A Cronbach's Alpha coefficient of 0.7 was used as the benchmark for reliability test.

\subsection{Pilot Survey}

A pilot survey was carried out by administering the questionnaire to ten randomly selected business owners in Ado Ekiti metropolis to ascertain further the validity of the research instrument and the appropriateness of questions asked in the survey questionnaire.

\subsection{Data Analysis Technique}

The data obtained are collected from respondents and were analysed statistically with the aid of the Statistical Package for Social Science (SPSS) software. The data were analysed using descriptive and inferential statistics. The descriptive statistics include; mean standard deviation, frequency and percentage, while the inferential statistics include multiple regressions using Ordinary Least Square (OLS). The study applies the ordinary least square (OLS) regression to test the hypotheses formulated in the study.

\subsection{Model Specification}

The model specified show how taxpayers' awareness and taxpayers' perception of government spending affect tax evasion and the moderating effect of taxpayers' attitude on the relationship between taxpayers awareness and tax evasion and between taxpayers perception of government spending and tax evasion.

$$
\mathrm{TE}=\beta_{0}+\beta_{1} \mathrm{TPA}+\beta_{2} \mathrm{TPP}+\beta 3 \mathrm{TPA} * \mathrm{TPAT}+\beta 4 \mathrm{TPP} * \mathrm{TPAT}+\mu
$$

Where:

$\mathrm{TE}=$ Tax Evasion 
$\beta 0=$ constant parameter

$\beta 1=$ coefficient of Taxpayers Awareness

$\beta 2=$ Coefficient of Taxpayers Perception

$\beta 3=$ coefficient of the moderating effect of taxpayers attitude on the relationship between Taxpayers awareness and Tax evasion

$\beta 4=$ coefficient of the moderating effect of Taxpayers attitude on the relationship between Taxpayers Perception of government spending and Tax Evasion

TPA $=$ Taxpayers' awareness

TPP = Taxpayers Perception of Government spending

TPAT $=$ Taxpayers attitudes

$\mu=$ error term

\section{Results and Discussion}

The study first and foremost ensured the validity and reliability of the instrument. It proceeded to factor analysis for further validation of the instrument and later proceeded to descriptive and inferential analysis.

\subsection{Pilot Study}

The study used ten companies for the pilot study, and the outcome reveals that on average, taxpayers were aware of tax existence and their civic responsibilities to pay tax. The pilot study also established the effect of taxpayers 'perceptions on tax evasion and also the moderating effect of taxpayers attitude on the relationship between taxpayers' perception and tax evasion. However, the effect of taxpayers' awareness of their tax responsibilities on tax evasion and the moderating effect of taxpayers' attitudes on the relationship between taxpayers' awareness and tax evasion lack statistical support.

\subsection{Validity and Reliability Test}

The study used content validity by making sure that various experts on tax matters reviewed the questionnaire before administering it to the respondents. The validity is essential to ensure that the instrument measures what it is supposed to measure. After certifying the validity of the instrument, the study proceeded to reliability test using Cronbach's Alpha.

Table 1. Reliability test

\begin{tabular}{lll}
\hline Variables & Cronbach' s Alpha & No of Items \\
\hline Tax Awareness & .853 & 5 \\
\hline Tax payers 'perceptions & .922 & 11 \\
\hline Taxpayers' Attitude & .781 & 8 \\
\hline Tax evasion & .935 & 7 \\
\hline
\end{tabular}

Source: Author's computation, 2020

The reliability test was conducted to ensure the internal consistency of the measurement. As shown in Table 1, all the variables are reliable since their Cronbach's Alpha coefficients are greater than 0.7.

\subsection{Factor Analysis}

The study also conducted a factor Analysis for each of the variables of the study to ensure that only essential questions are retained for the variable while the trivial ones are removed. The study used 0.4 as the benchmark for factor loadings since it is the threshold used in various empirical studies.

\subsubsection{Factor Analysis for Tax Awareness}

Table 2 present the factor analysis output for Taxpayers' awareness. 
Table 2. Factor analysis on tax awareness

\begin{tabular}{ll}
\hline Questionnaire Items & Factor Loading \\
\hline I know the amount of tax to pay & .780 \\
\hline I am aware that tax payment is my civic duty & .734 \\
\hline I am aware of the approved channel for tax collection in the state & .655 \\
\hline I am aware of tax and levies in the state & .540 \\
\hline I have been approached by tax officials to pay Tax & .496 \\
\hline
\end{tabular}

Source: Author's computation, 2020

The study asked five questions to measure tax awareness, and all the five questions were retained after the factor analysis because they all have factor loadings higher than 0.4 , which is the threshold that the study adopted.

\subsubsection{Factor Analysis for Taxpayers Perception of Government Spending}

In like manner, Table 3 shows the factor loading of the questions asked to measure taxpayers' perception of government spending.

Table 3. Factor analysis of taxpayers' perception about government spending

\begin{tabular}{lc}
\hline Questionnaire Items & Factor Loading \\
\hline The government officials do not judiciously spend taxpayers' money & .817 \\
\hline There is no justification for tax collected by the government & .797 \\
\hline Taxpayers' money is not used to provide the needed public goods & .792 \\
\hline The tax system is defective as it does not ensure accountability by government & .779 \\
\hline The process of tax collection is cumbersome, and it distorts business operations & .777 \\
\hline Tax payment is a means by which government exploits citizens & .765 \\
\hline Those in government often squander taxpayers' money & .743 \\
\hline Taxpayers do not derive any benefit from tax paid to the government & .733 \\
\hline Tax policy is designed to enrich specific individuals in government & .719 \\
\hline The tax amount is high, and the basis for the tax computation is unknown & .706 \\
\hline Tax officials are corrupt & .644 \\
\hline
\end{tabular}

Source: Author's computation, 2020

In like manner, the study asked 12 questions to measure taxpayers' perception of government spending, but 11 of them were retained for further statistical analysis since only 11 questions had factor loadings greater than 0.4 .

\subsubsection{Factor Analysis Taxpayers Attitude}

Similarly, Table 4 comprises the factor loading of each construct of Taxpayers' attitude

Table 4. Factor analysis of taxpayers' attitude

\begin{tabular}{llc}
\hline S/N & Questions on Taxpayers Attitude & $\begin{array}{c}\text { Factor } \\
\text { Loading }\end{array}$ \\
\hline 1 & Not declaring my extra income of NGN 20,000 on my tax return is a serious offence & .806 \\
\hline 2 & Claiming a nonexistent deduction of NGN 5,000 on my tax return is a serious offence & .777 \\
\hline 3 & $\begin{array}{l}\text { You can criticise a person who declares lower income than was the case on his/her tax } \\
\text { return when there are so many others doing the same }\end{array}$ & .772 \\
\hline
\end{tabular}




\begin{tabular}{llc}
\hline 4 & You can criticise others who exploit the many possibilities in the tax law to evade taxes & .692 \\
\hline 5 & You can defend people who evade taxes because the tax system is unfair & .687 \\
\hline 6 & Robbing a kiosk of NGN1,000 is a serious illegality & .542 \\
\hline 7 & $\begin{array}{l}\text { Embezzling NGN 10,000 from an association which you are a member is a severe } \\
\text { illegality }\end{array}$ & .538 \\
\hline 8 & Stealing a wallet containing NGN 500 is a severe illegality & .442 \\
\hline
\end{tabular}

Source: Author's computation, 2020

In the same way, eight questions were asked to measure taxpayers' attitude, and all of them were subjected to factor analysis. All of them were retained and subjected to further statistical analysis for having a factor loading, not below 0.4 .

\subsubsection{Factor Analysis for Tax Evasion}

In like manner, Table 5 below shows the factor loading of each of the question asked under tax evasion.

Table 5. Factors analysis of tax evasion

\section{Questionnaire Items}

As a taxpayer, you prefer to bribe tax officials than to pay the full amount of tax that you are 888 asked to pay based on your assessment

\begin{tabular}{lc}
\hline As a taxpayer, you do falsify records to avoid paying the required tax amount & .883 \\
\hline As a taxpayer, you desperately seek loopholes in tax administration to avoid paying Tax & .877 \\
\hline As a taxpayer, you don't usually pay tax whenever there is an avenue to do so & .866 \\
\hline As a taxpayer, you are not always willing to pay Tax & .866 \\
\hline Taxpayers consider tax amount to be too high; hence, you try to dodge the payment & .789 \\
\hline $\begin{array}{l}\text { As a taxpayer, you believe the tax is an additional cost to the business; hence you try to } \\
\text { eliminate it }\end{array}$ & \\
\hline Extraction Method: Principal Component Analysis.
\end{tabular}

Source: Author's computation, 2020

As regards Tax evasion, which is the dependent variable of the study, eight questions were asked and subjected to factor analysis. All the questions were retained and subjected to further statistical analysis for having factor loadings higher than 0.4 .

\subsection{Diagnostic Test}

Before proceeding to inferential Analysis, the study first and foremost ensured that the associated assumptions for the analytical technique exist. The assumptions that were tested include Normality, Homoscedasticity, Linearity and Multicollinearity.

\subsubsection{Normality Test}

The study tested for normality of data to know whether to proceed with the parametric test or use non-parametric tests. The study used both Shapiro-Wiki and Kolmogorov-Smirnov tests but based its decision on Shapiro-Wiki results because Shapiro-Wiki is said to be more reliable for small samples lesser than 200. Since their p-values are higher than .05 , it means their deviation from normality is not significant, which means they are normally distributed. 
Table 6. Test for normality

\begin{tabular}{lllllll}
\hline Tests of Normality & \multicolumn{7}{l}{ Shapiro-Wilk } \\
\hline & \multicolumn{2}{l}{ Kolmogorov-Smirnov ${ }^{\mathrm{a}}$} & \multicolumn{4}{l}{} \\
\cline { 2 - 7 } & Statistic & $\mathrm{df}$ & Sig. & Statistic & $\mathrm{df}$ & Sig. \\
\hline Awareness & .181 & 40 & .002 & .928 & 40 & .114 \\
\hline Perception & .136 & 40 & .059 & .951 & 40 & .083 \\
\hline Attitude & .192 & 40 & .001 & .924 & 40 & .060 \\
\hline Tax evasion & .201 & 40 & .000 & .890 & 40 & .071 \\
\hline
\end{tabular}

Source: Author's computation, 2020

According to Table 6 , the p-values for the variables are $.114, .083,060$ and .071 for awareness, perception, Attitude and Tax evasion respectively. Since the probability values are higher than 0.05 , which is the significant value that this study adopts, it implies that the data are not significantly deviated from normal. This outcome indicates that the data are normally distributed.

\subsubsection{Heteroscedasticity Test}

After certifying the normality of data, the study proceeded to test for heteroscedasticity. This test was done to ensure a constant variation of the error term, which is one of the assumptions of OLS.

Table 7. Heteroscedasticity glesjer test

\begin{tabular}{llllll}
\hline \multicolumn{7}{l}{ Heteroscedasticity Glesjer Test } & \multicolumn{2}{l}{} \\
\hline \multicolumn{7}{l}{ Unstandardised coefficients } & Standardised Coefficients & \\
\hline & $\mathrm{B}$ & Std. Error & Beta & $\mathrm{t}$ & Sig \\
\hline Constant & 5.569 & 1.935 & & 2.878 & .005 \\
\hline Awareness & 0.35 & 0.37 & .081 & .945 & .432 \\
\hline Perception & .031 & .039 & .079 & .777 & .439 \\
\hline Attitude & -163 & .140 & -.119 & -1.164 & .247 \\
\hline
\end{tabular}

Source: Author's computation, 2019

Glesjer test was used to know whether the assumption of homoscedasticity is violated or not, and the output shows that there is no problem of heteroscedasticity since the P-value for awareness $(0.432)$, perception $(0.439)$ and the p-value for attitude $(0.247)$ are greater than 0.05 .

\subsubsection{Multicollinearity Test}

The study tested for multicollinearity using the Variance Inflation Factor (VIF). Based on the VIF for each of the variables which are higher than one but less than ten and the Tolerance values which are greater than 0 but less than 1, it implies that the independent variables do not collinear with each other. Tolerance (TOL) can also be used as a measure of multicollinearity, given its intimate connection with VIF. The closer the tolerance to zero, the higher the degree of collinearity of that variable with the other regressor hence, the closer TOLj is to 1 , the higher the evidence that independent variable is not collinear with the other regressors.

Table 8. Multicollinearity test using variance inflation factor and tolerance

\begin{tabular}{llllll}
\hline Multicollinearity Test & & & & \\
\hline Model & Unstandardised & Standardised & & \\
Coefficients & Coefficients & $\mathrm{t}$ & Sig. & Collinearity Statistics \\
\hline
\end{tabular}




\begin{tabular}{lllllllll}
\hline \multicolumn{2}{c}{ B } & Std. Error & Beta & & Tolerance & VIF \\
\hline 1 & (Constant) & 4.353 & 3.141 & & 1.386 & .169 & & \\
\cline { 2 - 8 } Awareness & .452 & .070 & & .6457 & .076 & .742 & 1.781 \\
\cline { 2 - 8 } & Perception & .441 & .064 & .578 & 6.914 & .000 & .675 & 1.526 \\
\hline Attitude & .051 & .228 & .019 & .223 & .824 & .695 & 1.836 \\
\hline
\end{tabular}

a. Dependent Variable: Tax Evasion

Source: Author's computation, 2019

According to Table 8, the VIF are 1.781, 1.526 and 1.836 for Awareness, Perception and Attitude, respectively. Since the VIF for each explanatory variable is higher than one but less than ten, it implies there is no multicollinearity problem. Likewise, since Tolerance values $(.742, .675$ and. 695$)$ are also higher than 0 but less than 1 , it implies that each predictor of the study is independent of each other and can individually add a meaningful contribution to the study.

\subsubsection{Linearity Test}

The study also tested for linearity before using ordinary least square since the model for this study was stated in linear form.

Table 9. Linearity test for tax evasion and awareness

\begin{tabular}{llll}
\hline Variables & & F & Sig. \\
\hline Tax evasion * awareness & Linearity & .971 & .335 \\
\cline { 2 - 4 } & Deviation from Linearity & 1.011 & .481
\end{tabular}

Source: Author's computation, 2020

The significant value (0.481) on deviation from linearity shown in Table 9 for tax evasion and awareness is higher than 0.05 , which indicate that the independent variable does not significantly deviate from linearity. This result connotes that the independent variable has a linear relationship with the dependent variable.

Table 10. Linearity test for tax evasion and taxpayers 'attitude

\begin{tabular}{llll}
\hline Variables & & F & Sig. \\
\hline Tax evasion * Taxpayers attitude & Linearity & 1.297 & .258 \\
\cline { 2 - 4 } & Deviation from Linearity & 1.696 & .087 \\
\hline
\end{tabular}

Source: Author's computation, 2020

Also, since the significant value (0.087) on deviation from linearity shown in Table 10 for tax evasion and taxpayers' attitude is higher than 0.05 , it can be concluded that there is a linear relationship between the dependent variable (Tax evasion) and the independent variable (Taxpayers' Attitude) as it indicates that the independent variable does not significantly deviate from linearity.

Table 11. Linearity test for taxpayers' perception and tax evasion

\begin{tabular}{llll}
\hline Variables & & F & Sig. \\
\hline Tax evasion * Taxpayers 'perception & Linearity & 65.047 & .000 \\
\cline { 2 - 4 } & Deviation from Linearity & 1.981 & .110 \\
\hline
\end{tabular}

Source: Author's computation, 2020 
Similarly, since the p-value for deviation from linearity is 0.110 which is higher than 0.05 as shown in Table 11 , the study concludes that there is a linear relationship between the dependent (Tax evasion) and the independent variable (Taxpayers' perception)

\subsection{Taxpayers Awareness, Perceptions, Attitude and Tax Evasion}

The effect of taxpayers' awareness of their civic duties to pay tax and their perception about government spending are tested on tax evasion. Likewise, the moderating effect of their attitude on the relationships between their awareness and tax evasion and their perception and tax evasion were tested in this section.

\subsubsection{Model Fitness}

This section discussed the fitness of the model. $\mathrm{R}$ represents the multiple correlations among the variables of the study in Table 12 below.

Table 12. Model summary

\begin{tabular}{|c|c|c|c|c|c|c|c|c|c|}
\hline \multirow[b]{3}{*}{ Model } & \multirow[b]{3}{*}{$\mathrm{R}$} & \multicolumn{7}{|c|}{ Std. The error Change Statistics } & \multirow[b]{3}{*}{ Sig. F Change } \\
\hline & & & Adjusted & Rof & theR & Square & & & \\
\hline & & R Square & Square & Estimate & Change & F Change & df1 & df2 & \\
\hline$\overline{1}$ & $.490^{\mathrm{a}}$ & .240 & .153 & 4.86356 & .442 & 26.282 & 5 & 166 & .000 \\
\hline 2 & $.702^{\mathrm{b}}$ & .493 & .465 & 4.69191 & .253 & 4.092 & 4 & 162 & .003 \\
\hline
\end{tabular}

Source: Author's computation, 2020

The coefficient of correlation which is .490 indicates a moderate relationship between taxpayers' awareness, perception and tax evasion. $\mathrm{R}$ square also known as coefficient of determination implies that taxpayers' awareness and perception about government spending contribute only about $24.0 \%$ of the factors that affect tax evasion while the remaining $86.0 \%$ are represented by error term. However, when the moderator was added, the contribution to the changes in tax evasion increased to 49.3. Therefore, taxpayers' attitudes significantly contribute additional $25.3 \%$ variance in tax evasion ( $\mathrm{R}-$ Square change $=.253, \mathrm{p}=.003>.05)$.

Table 13. Model fitness 2

\begin{tabular}{lllllll}
\hline \multicolumn{1}{l}{ ANOVA } & & & & & \\
\hline Model & & Sum of Squares & df & Mean Square & F & Sig. \\
\hline 1 & Regression & 503.697 & 4 & 125.924 & 2.763 & $.043^{\mathrm{b}}$ \\
\cline { 2 - 7 } & Residual & 1595.403 & 35 & 45.583 & & \\
\cline { 2 - 6 } & Total & 2099.100 & 39 & & & \\
\hline
\end{tabular}

Source: Author's computation, 2020

In the same vein, the significant value in Table 13, which is 0.043 implies that the model is fit, and at least one of the variables is significant.

\subsection{Hypotheses Testing}

This section comprises the regression outputs and interpretations.

Table 14. Regression output

\section{Coefficients}

\begin{tabular}{llllll}
\hline \multirow{2}{*}{ Model } & \multicolumn{4}{l}{ Unstandardised Coefficients } & \multicolumn{2}{l}{ Standardised Coefficients } & \\
\cline { 2 - 5 } & $\mathrm{B}$ & Std. Error & Beta & $\mathrm{t}$ & Sig. \\
\hline $1 \quad$ (Constant) & 39.143 & 9.049 & & 4.326 & .000 \\
\hline
\end{tabular}




\begin{tabular}{lllllll} 
Attitude*Awareness & .187 & .065 & 2.910 & 2.870 & .007 \\
\hline Attitude* perception & -.085 & .044 & -1.609 & -1.955 & .059 \\
\hline Perception & .647 & .522 & .716 & 1.241 & .223 \\
\hline Awareness & -3.128 & 1.011 & -2.127 & -3.094 & .004 \\
\hline
\end{tabular}

a. Dependent Variable: Tax evasion

Source: Author's computation, 2020

According to Table 14, the p-value for taxpayers' awareness is .004 which is lower than 0.05 implies that taxpayers' awareness has a significant effect on tax evasion in the informal sector of Ado-Ekiti at 5\% level of significance ( $\beta=$ $-3.128, \mathrm{p}=.004)$. Therefore, the first hypothesis of this study which states that "tax awareness does not have a significant effect on tax evasion among the informal enterprises in Ekiti state." cannot be rejected. This study implies that a unit increase in tax awareness reduces tax evasion by 3.128 units. This outcome implies that awareness of taxpayers of their civic responsibilities reduces tax evasion among the taxpayers in the informal sector of Ekiti state.

However, as shown in Table 14, the p-value for perception is .223 which is higher than 0.05 ( $\beta=0.647, \mathrm{p}=.233$ ). This output implies that the null hypothesis 2 for this study which states that "Taxpayers' perception about government spending does not have a significant effect on tax evasion in the informal sector of Ado-Ekiti" cannot be rejected. It means taxpayers' perception does not have a statistically significant effect on tax evasion at a 5\% level of significance. However, the coefficient of taxpayers' perception, which is 0.647 indicates that every 1-unit increase in taxpayers' perception leads to 0.647 increase in the tax evasion.

Also, the p-value for moderating effect of attitude on the relationship between taxpayers' awareness and tax evasion in the informal sector of Ado-Ekiti which is .007 shows that taxpayers' attitude has a significant moderating effect on the relationship between taxpayers' awareness and tax evasion $(\beta=.187, \mathrm{p}=.007)$. Therefore, the third hypothesis of this study which says that "Taxpayers' Attitude does not have a significant moderating effect on the relationship between taxpayers' awareness of their civic responsibilities to pay tax and tax evasion among the taxpayers in the informal sector of Ado-Ekiti" is hereby rejected. The coefficient of the variable, which is .187, also implies that every one-unit increase in taxpayers' awareness and taxpayers' attitude combined will increase tax evasion by .187. The coefficient of the variable, which is .187 compared with -3.128 for taxpayers' awareness shows the moderating effect of taxpayers' attitude. This outcome shows that even though taxpayers' awareness of their civic responsibilities to pay tax reduces tax evasion, still, their wrong attitude always to evade tax reverses the positive effect of tax awareness.

Equally, the p-value of .059 in Table 14 shows that taxpayers' attitude does not have a significant moderating effect on the relationship between taxpayers' perception and tax evasion at $5 \%$ level of significance $(\beta=-0.85,=p=0.59)$. Therefore, the fourth hypothesis of this study which states that "Taxpayers' Attitude does not have a significant moderating effect on the relationship between taxpayers' perceptions about government spending and tax evasion among the taxpayers in the informal sector of Ado-Ekiti" cannot be rejected. The coefficient of the variable shows a negative and insignificant moderating effect -0.085 compared with 0.647 for perception alone when the interaction effect of taxpayers' attitude was not added. This outcome also shows that a unit increase in taxpayers attitude combined with taxpayers' perceptions about government spending reduces tax evasion by 0.85 .

\subsection{Discussion of Findings}

This section comprises the discussion and interrogation of findings of this study in relations to the objectives of the study and the previous studies.

\subsubsection{Taxpayers Awareness and Tax Evasion}

The first objective of this study was to find out the effect of taxpayers 'awareness on tax evasion. Since the p-value of the variable is lower than 0.05 , it implies that the taxpayers 'awareness has a significant effect on tax evasion. The coefficient of the variable, which is -3.128 implies that every one unit increase in taxpayers' awareness leads to 3.128 units decrease in tax evasion. This outcome indicates that the more people are aware of their tax responsibilities, the less they evade tax. The more they see tax as their civic responsibilities, the more they know where to pay their tax and the amount to pay among many others, the less they evade tax. This finding lends credence to some of the previous findings (Lodha et al., 2017; Zhang et al., 2016). However, this finding contradicts some of the previous findings (Beesoon et al., 2016; Chuenjit, 2014; Ndekwa, 2014; Saad, 2014). 


\subsubsection{Taxpayers' Perception and Tax Evasion}

The second objective of the study was to evaluate the effect of taxpayers' perception on tax evasion by unregistered business owners in Ado-Ekiti metropolis. The study found out that taxpayers' perception does not have a significant effect on tax evasion. This outcome could be that the taxpayers have wrong perceptions about tax which make them not willing to pay tax. This result might also be because the payment of tax by taxpayers is not a voluntary action; that is, it is not dependent on whether the government provides social amenities or not. This finding lends credence to some of the previous (Aronmwan \& Eragbhe, 2015; Engida \& Baisa, 2014). It, however, contradicts some of the earlier findings (Sritharan \& Salawati, 2019).

\subsubsection{Taxpayers Attitude, Awareness and Tax Evasion}

The third objective of the study was to evaluate the moderating effect of taxpayers ' attitude on the relationship between the taxpayers' awareness and tax evasion in the informal sector of Ado-Ekiti. The study established that taxpayers' attitudes have a significant effect on the relationship between tax payer's awareness and tax evasion. This result implies that when taxpayers attitude combines force with taxpayers' awareness, they have a statistically significant effect on tax evasion. Taxpayers' awareness alone reduces tax evasion, which implies that the more the taxpayers are aware of their tax responsibilities, the less they evade tax. However, when the attitude interacts with the awareness, the effect of awareness on tax evasion was drastically reduced. This result indicates that despite enough awareness of the taxpayers of their tax responsibilities, their attitudes will still make them evade tax no matter how little. However, this finding contradicts the earlier findings that taxpayers attitude reduce tax evasion (Alabede et al., 2011).

\subsubsection{Taxpayers' Attitude, Perceptions and Tax Evasion}

The fourth objective of the study was to assess the moderating effect of taxpayers' attitude on the relationship between taxpayers' perception and tax evasion in the informal sector of Ado-Ekiti. The result of the study showed that taxpayers' attitude does not have a significant effect on the relationship between the taxpayers' perception and tax evasion in the informal sector of Ado-Ekiti at 5\% level of significance. This outcome implies that when taxpayers' attitude combine force with taxpayers' perception, their impact on tax evasion was not significant.

Even though the previous studies did not carry out a moderating effect of taxpayers' attitude on the relationship between taxpayers' perception about government spending and tax evasion, but the similar studies revealed that taxpayers' positive attitude reduces tax evasion (Pui et al., 2017) and that taxpayers' attitude towards tax evasion has a significant positive effect on tax compliance behaviour (Alabede et al., 2011). However, studies from Nigeria show that taxpayer's attitude has a significant positive effect on compliance, while taxpayers perception does not have a statistically significant effect on tax compliance (Aronmwan \& Eragbhe, 2015).

\section{Conclusion}

This study has empirically established that Taxpayers' awareness can considerably reduce Tax evasion in the informal sector of Ekiti state. The study has also established that Taxpayers attitude has a significant moderating effect on the relationship between Tax awareness and Tax evasion. Likewise, this study concludes that Taxpayers 'perception about government spending and the moderating effect of Taxpayers' attitude on the relationship between Taxpayers perceptions of government spending and Tax evasion lack statistical support.

This study has enhanced the existing knowledge on the roles of Tax awareness and Taxpayers perceptions in tax evasion in Nigeria, particularly in the informal sector of Ekiti state which many earlier authors have not examined. The moderating effect of Taxpayers' attitude also contributed to the uniqueness of this study as the previous authors either used it as an independent variable or a mediating variable.

The unwillingness of the respondent to answer questionnaire was also experienced in this study as only 100 respondents completed and returned their questionnaire. Moreover, the authors are not sure of the total population since they are not registered. Only those members that registered with their association in Ado-Local government were examined.

Future authors are advised to examine the informal sector of other local government in Ekiti state and other states. In a state where there are many members registered with their association, future researchers may consider examining each sector separately and comparatively.

\section{References}

Alabede, J. O., Ariffin, Z. Z., \& Idris, K. (2011). Individual taxpayers' attitude and compliance behaviour in Nigeria: The moderating role of financial condition and risk preference. Journal of Accounting and Taxation, 3(6), 
91-104.

Alqtish, A., Alqirem, R., \& Kasem, F. (2018). The impact of electronic tax auditing on the reduction of tax evasion from the perspective of the income and sales tax department in Jordan. Journal of Accounting, Finance and Management Strategy, 13(1), 77-104.

Aronmwan, E., \& Eragbhe, E. (2015, May). Taxpayers income, taxpayers attributes and personal income tax compliance. African Journal of Management Sciences, 1, 95-111.

Assfaw, A. M., \& Sebhat, W. (2019). Wondimu sebhat. Journal of Accounting, Finance and Auditing, 5(1), 32-59. https://doi.org/10.32602/jafas.2019.2

Beesoon, D., Hemavadi, P. S., \& Jugurnath, B. (2016). Assessing the determinants of income tax compliance in mauritius: a study of individual taxpayers. Proceedings of the Fifth Asia-Pacific Conference on Global Business, Economics, Finance and Social Sciences (AP16Mauritius Conference), 21-23.

Chuenjit, P. (2014). The culture of taxation: definition and conceptual approaches for tax administration. Journal of Population and Social Studies, 22(1), 14-34. https://doi.org/10.14456/jpss.2014.4

Dube, G., \& Casale, D. (2016). The implementation of informal sector taxation: Evidence from selected African countries. Journal of Tax Research, 14(3), 601-623.

Elena, D. A., Alberto, D. B. M., \& Giuseppe, S. (n.d.). Tax Evasion, government size and taxpayers perceptions on public goods provision, evidence from italian regions (pp. 1-25).

Engida, T. G., \& Baisa, G. A. (2014). Factors Influencing t axpayers' compliance with the tax system: An empirical study in Mekelle City, Ethiopia. Journal of Tax Research, 12(2), 433-453.

Eriksen, K., \& Fallan, L. (1996). Tax knowledge and attitudes towards taxation; A report on a quasi-experiment. Journal of Economic Psycology, 17(3), 387-402.

Hartikayanti, H. N., \& Siregar, I. W. (2019). Effect of motivation and awareness on tax compliance among SME'S: (Case Study in Cimahi, Indonesia). International Journal of Organisational Innovation, 12(1), 255-266.

Kaplanoglou, G., Rapanos, V. T., \& Daskalakis, N. (2016). Tax compliance behaviour during the crisis : the case of Greek SMEs. European Journal of Law and Economics, 42(3), 405-444. https://doi.org/10.1007/s10657-016-9547-y

Lodha, S., Sheikh, A. A., \& Soral, G. (2017). Tax ethics and tax compliance: Exploring the opinions of tax professionals of India. Journal of Accounting Research and Audit Practices, XVI(4), 44-66.

Mansor, M., \& Gurama, Z. (2016). The determinants of tax evasion in gombe state Nigeria. International Journal of Economics and Financial Issues, 6(2010), 165-170.

Mitu, N. E. (2018). A basic necessity of a modern fiscal policy: voluntary compliance. RSP, (57), 118-130.

Ndekwa, A. G. (2014). Factors for improving tax compliance among small and medium enteprises in Tanzania. International Journal of Business and Management, 2(10), 285-290.

Olaoye, C. O., \& Ogundipe, A. A. (2018). Application of tax audit and investigation on tax evasion control in Nigeria. Journal of Accounting, Finance and Auditing Studies, 4(1), 79-93.

Omodero, C. O. (2019). Tax evasion and its consequences on an emerging economy : Nigeria as a focus. Reserach in World Economy, 10(3), 127-135. https://doi.org/10.5430/rwe.v10n3p127

Pui, Y. C., Moorthy, K., \& Choo, K. S. W. (2017). Taxpayers' perceptions on tax evasion behaviour: an empirical study in Malaysia. Journal of Law and Management, 59(3), 413-429. https://doi.org/10.1108

Rantelangi, C., \& Majid, N. (2018, January). Factors that influence the taxpayers perception on the tax evasion. Advances in Economics, Business and Management Research, 35, 219-225. https://doi.org/10.2991/miceb-17.2018.34

Razak, A. A., \& Adafula, C. J. (2013, September). Evaluating taxpayers' attitude and its influ ence on tax compliance decisions in Tamale, Ghana. Journal of Accounting and Taxation, 5, 48-57. https://doi.org/10.5897/JAT2013.0120

Saad, N. (2014). Tax knowledge, tax complexity and tax compliance: taxpayers' view. Procedia - Social and Behavioral Sciences, 109(1), 1069-1075. https://doi.org/10.1016/j.sbspro.2013.12.590

Sritharan, N., \& Salawati, S. (2019). Economic factors impact on individual taxpayers' tax compliance behaviour in 
Malaysia. Nternational Journal of Academic Research in Accounting, Finance and Management Sciences, 9(2), 172-182. https://doi.org/10.6007/IJARAFMS/v9-i2/6166

Tilahun, M. (2018). Determinants of tax compliance: a case of gondar city. Research Journal of Finance and Accounting, 9(13), 38-45.

Zhang, J., Abukhadijeh, M. A., \& Qasem, M. F. (2016). Tax evasion and tax awareness evidence from Jordan. International Business Research, 9(12), 65-75. https://doi.org/10.5539/ibr.v9n12p65

\section{Appendix A}

\section{Research Instrument}

Section A: Respondents bio data

Type of Business (e.g. fashion designer etc):

Gender: Male [ ] Female [ ]

Age: Below 30 years [ ] 30-35 years [ ] 36-40 years [ ] 40 years \& above [ ]

Highest academic qualification: SSCE [ ] ND/NCE [ ] First degree [ ] Masters [ ] Ph. D [ ]

Professional qualification: CIBN [ ] ICAN/ACCA [ ] others (Pls specify)

Work experience: Below 1 year [ ]1-5 years [ ]6-10 years [ ] 11 years \& above [ ]

Management level: Top level [ ] Middle level [ ] Low level [ ]

Section B: Please tick the most appropriate options.

NOTE: SA =Strongly Agree, A = Agree, U =Undecided, D=Disagree, SD =Strongly Disagree

Table A1. Taxpayers' awareness of their civic duties to pay tax

\begin{tabular}{|c|c|c|c|c|c|c|}
\hline $\mathbf{S} / \mathbf{N}$ & Questionnaire Items & $\mathbf{S A}$ & $\mathbf{A}$ & $\mathbf{U}$ & $\mathbf{D}$ & SD \\
\hline 1 & I have knowledge of the amount of tax to pay & . & & & & \\
\hline 2 & I am aware that tax payment is my civic duty & & & & & \\
\hline 3 & I am aware of the approved channel for tax collection in the state & & & & & \\
\hline 4 & I am aware of tax and levies in the state & & & & & \\
\hline 5 & I have been approached by tax officials to pay tax & & & & & \\
\hline
\end{tabular}

Table A2. Taxpayers' perception of government spending

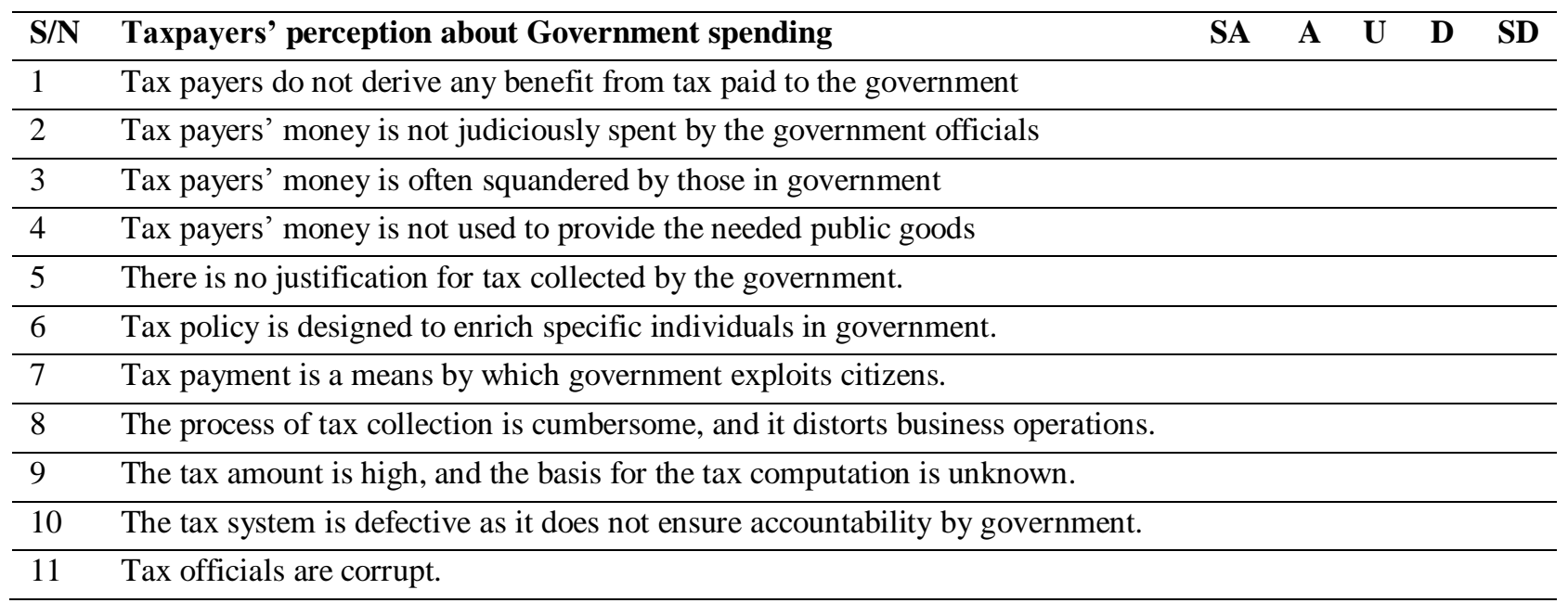


Table A3. Taxpayers' attitude

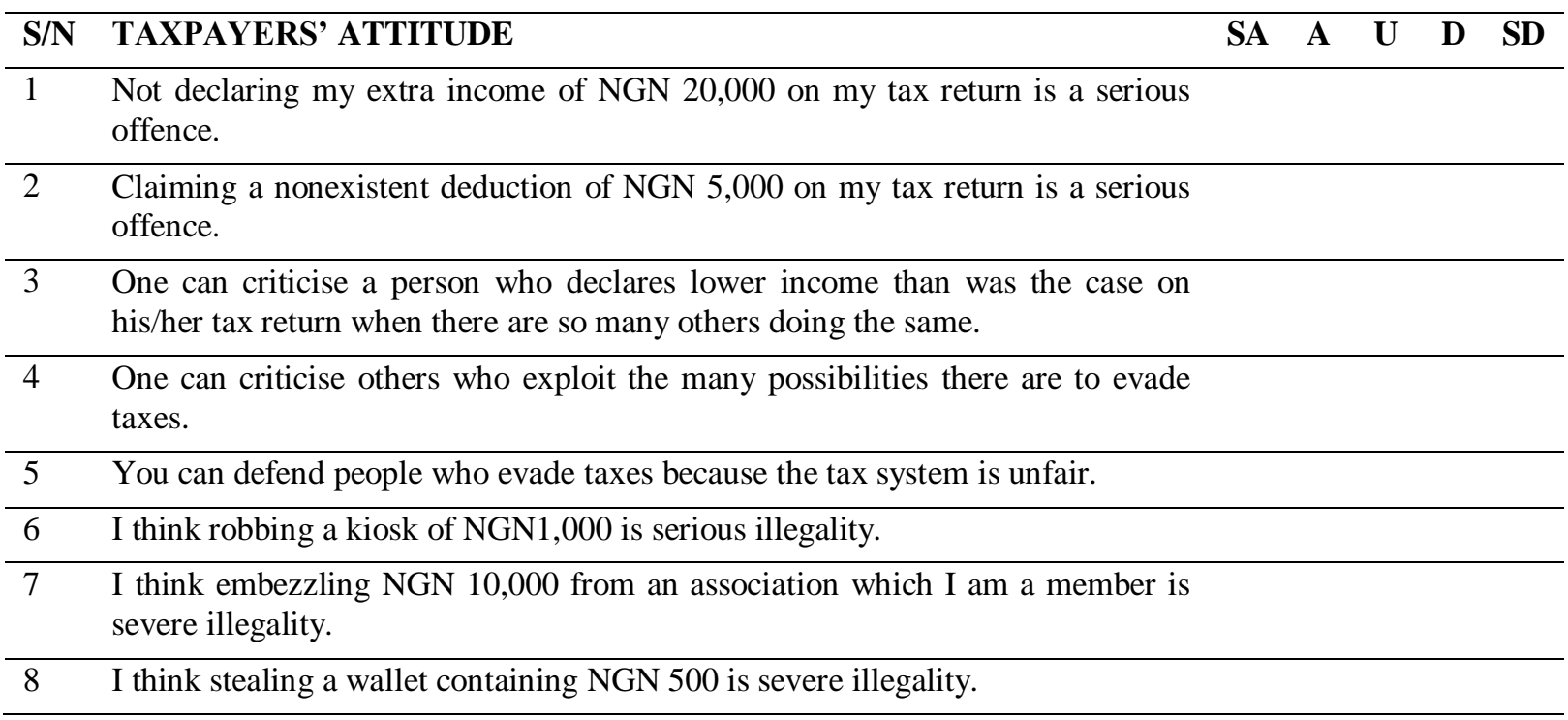

Table A4. Tax evasion

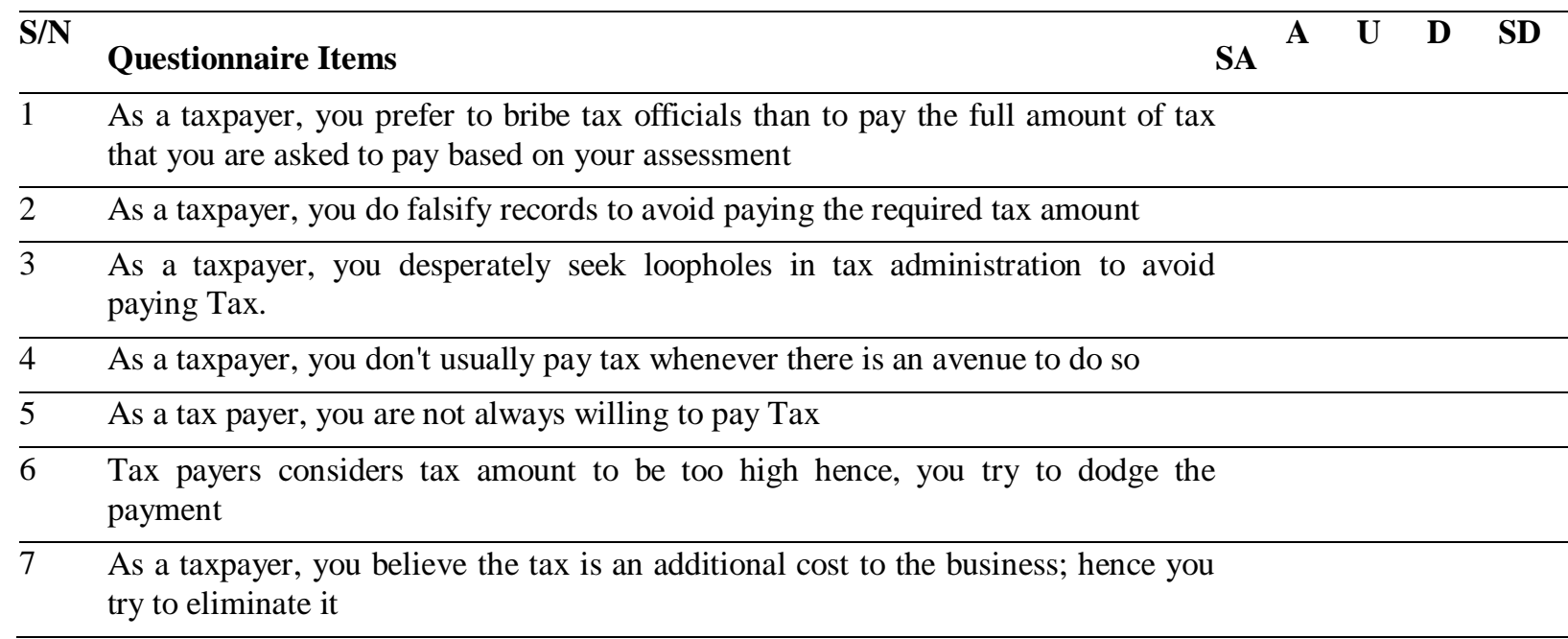

\section{Appendix B}

Selected Sampled Unregistered Businesses in Ado-Ekiti Metropolis

\begin{tabular}{llll}
\hline S/No & Description & Frequency & Percentage (\%) \\
\hline 1 & Barbing Salon & 5 & 5 \\
\hline 2 & Beautician/Makeup Artist & 5 & 5 \\
\hline 3 & Boutique/Cloth Merchant & 6 & 6 \\
\hline 4 & Building Material Store & 1 & 1 \\
\hline 5 & Business/CBT Centre & 7 & 7 \\
\hline 6 & Catering/Confectionary & 3 & 3 \\
\hline 7 & Coaching Centre & 3 & 3 \\
\hline 8 & Computer Accessory & 1 & 1 \\
\hline
\end{tabular}




\begin{tabular}{|c|c|c|c|}
\hline 9 & Electronic Store & 2 & 2 \\
\hline 10 & Fashion Designer & 6 & 6 \\
\hline 11 & Filling Station & 2 & 2 \\
\hline 12 & Food Canteen/Restaurant & 7 & 7 \\
\hline 13 & Gas Station & 4 & 4 \\
\hline 14 & Graphics Designer & 4 & 4 \\
\hline 15 & Hair Dressing & 5 & 5 \\
\hline 16 & Hotel \&Bar & 2 & 2 \\
\hline 17 & Industrial Welding & 1 & 1 \\
\hline 18 & Journalism & 5 & 5 \\
\hline 19 & Kids Store & 1 & 1 \\
\hline 20 & Laundry & 1 & 1 \\
\hline 21 & Medicine Store & 4 & 4 \\
\hline 22 & Phone Store & 4 & 4 \\
\hline 23 & Photo Studio & 1 & 1 \\
\hline 24 & Plastic Factory & 1 & 1 \\
\hline 25 & Printing Press & 5 & 5 \\
\hline 26 & Private Nursery School/Crèche & 5 & 5 \\
\hline 27 & Provision Store & 1 & 1 \\
\hline 28 & Shoe Making & 1 & 1 \\
\hline 29 & Sporting Bet & 2 & 2 \\
\hline 30 & Trading & 3 & 3 \\
\hline 31 & Veterinary Store & 2 & 2 \\
\hline Total & & 100 & 100 \\
\hline
\end{tabular}

\section{Copyrights}

Copyright for this article is retained by the author(s), with first publication rights granted to the journal.

This is an open-access article distributed under the terms and conditions of the Creative Commons Attribution license (http://creativecommons.org/licenses/by/4.0/). 